\title{
Static and dynamic
}

\section{impacts of MERCOSUR: the case of the pharmaceutical sector}

\section{Marta Bekerman}

Director

bekerman@econ.uba.ar

Pablo Sirlin

Researcher

psirlin@sepyme.gov.ar

Centre for Studies on the Economic Structure (CENES),

Faculty of Economic Sciences,

University of Buenos Aires
This article analyses the impact of MERCOSUR on the pharmaceutical sector. It concludes, among other things, that the sector suffered strong impacts, both static and dynamic, as a result of the integration process. From the static point of view, it may be observed that integration has given rise to a marked increase in intrazonal trade, which reflects the existence of a substantial trade creation process in MERCOSUR. From the dynamic point of view, the outstanding aspect is the increasing interest in regaining a place in the markets of Argentina and Brazil shown by transnational corporations since the integration process. This process, together with the changes in the regulations on medical patents, has given rise to big changes in the strategies and positions of laboratories of domestic origin. 


\section{Introduction}

Not only is the evaluation of the benefits of integration processes a difficult task, as also is the appraisal of their costs, but moreover there is no consensus as to how to carry it out.

Most economic studies consider that the static effects in terms of creation or diversion of trade are the fundamental variable for such evaluation. However, these effects leave out the potential dynamic benefits that may be derived from the integration process, such as the development of technological change, of learning processes, of production specialization, etc. These dynamic effects are those which provide the most convincing arguments in favour of integration processes, as compared with arguments in favour of the unilateral opening of the economy. The problem arises, however, with regard to the difficulties in measuring these benefits, since they cannot be determined solely on the basis of analyses of growth rates or of the behaviour of regional trade flows.

These difficulties point to the need for methods of working at a more disaggregated level, which would make it possible to identify processes that could not be detected at the global level. In order to do this, we analysed the changes which took place within each sector of production, ${ }^{1}$ in order to determine the effects on the levels and forms of organization of production, business strategies, levels of technological modernity, the regional dynamics of the sector, etc. This type of analysis calls, as far as possible, for the isolation of the effects of integration processes from the effects of the other changes which are taking place in the economies of the area (processes of greater openness, privatization, etc.). This provides us with suitable elements for determining what kind of national or community policies could be applied in the future in order to make MERCOSUR a dynamic element in production development.

In line with this methodological approach, in the present article we will analyse the impact of MERCOSUR

\footnotetext{
${ }^{1}$ This is because each sector is affected very differently, either because of its previous situation as regards competitiveness, the possibilities of taking advantage of latent demand in other markets, or the special ways in which differences between the levels of regulation of partner countries affect the sector.
}

on the pharmaceutical sector. ${ }^{2}$ This is a very interesting sector from the point of view of analysing the effects of regional integration because of its strategic importance, the fact that it has registered growing intrazonal and extra-zonal trade flows, and the profound changes it is undergoing both at the world level and within the countries making up the MERCOSUR zone. Thus, the cost and way of financing the population's access to medicines is and always has been a source of considerable concern for governments, while the level of technological innovation and dynamic efficiency attained by the sector can be an important factor in its insertion in regional and world markets.

Anticipating the findings set forth later in this article, it may be noted that the sector has suffered strong static and dynamic impacts as a result of the integration process. Firstly, the integration of the MERCOSUR area has given rise to a marked increase in intra-area trade: as imports from outside the area have also increased but production levels have grown much less, it may be inferred that a considerable trade creation process has taken place in MERCOSUR. The dynamic impacts are due to different causes, including the growing interest displayed by transnational corporations, in the light of the integration process, in strengthening their positions in the Argentine and Brazilian markets because of the greater possibilities of expanding intra-company trade.

The pharmaceutical sector displays an increasing degree of internationalization, and at the world level it is dominated by a handful of companies whose efforts in the field of competition are based on the ongoing introduction of new products through scientific and technological research as well as on heavy expenditure on marketing and publicity for their existing products. Indeed, within the region the proprietary ethical drugs

\footnotetext{
2 The pharmaceutical sector forms part of a chain of production which begins with the discovery of a molecule or active principle and culminates in the industrial production of pharmaceuticals. These two stages make up the "pharmaceutical industry", which is part of what is generally known as the "fine chemicals industry". The pharmaceutical industry proper, which will be analysed in this article, comprises the production and marketing of pharmaceutical specialities or medicines.
} 
segment is clearly dominated by the big transnational corporations. ${ }^{3}$ These corporations act very dynamically as regards the location of their plants and their national specialization patterns.

In the case of generic products, capacity for innovation and marketing expenditure play only a secondary role: price competition is the key factor, and this makes it necessary to pay more attention to process technologies and economies of scale.

In most of the countries, in addition to the transnationals there are also local-capital firms which produce pharmaceutical specialities. These firms use generic drugs, which cost less than the corresponding patented drugs, as their inputs, and they carry out hardly any research activities, although they do spend a certain amount on product development. They compete with each other and with the subsidiaries of the big transnationals on the basis of price and marketing costs, and the brand name and corporate image are fundamental elements of competition. In the case of ethical products, the marketing effort is aimed at the medical profession, because it is the doctors who prescribe one or another specific medicine for their patients. In the case of products which are sold freely to the public, the competition is based on the brand name, promoted through intensive mass publicity.

The intrinsic nature of the products of this industry, which are intended for public health purposes, as well as the importance of scientific and technological research activities, make this a highly regulated sector. ${ }^{4}$

First of all, we will look at the asymmetries in regulations between Argentina and Brazil (section II) and the performance of the sector in the individual MERCOSUR countries (section III), concluding with an appraisal of the static and dynamic effects of the integration process, as identified from statistical analysis and field studies in Brazil, Uruguay and Argentina $^{5}$ (section IV).

\section{II}

\section{Policy asymmetries in MERcosUR}

The policy asymmetries in MERCOSUR may be observed in two fields: in the global policies for the promotion of investment, production, innovation and exports, and in the differences in the regulatory framework specificically affecting the pharmaceutical sector.

During the import substitution industrialization phase, the MERCOSUR countries, and especially Argentina and Brazil, developed a wide range of promotion instruments which combined high rates of trade protection with special investment promotion regimes and, later, export promotion measures. Towards the end of the 1980s, the MERCOSUR countries embarked on a reform process aimed at economic liberalization and at the elimination of the State promotion and

\footnotetext{
${ }^{3}$ Medicines for human consumption are divided into ethical and non-ethical drugs. The first group comprises all those medicines which are sold exclusively on a doctor's prescription, and they may be further divided into generic and proprietary medicines. Generic medicines are those whose patents have run out, so that they can now be freely manufactured. Proprietary medicines, in contrast (in countries which accept the corresponding rules), can only be manufactured by the patent-holders or under licence from the latter, so they generally cost more. Non-ethical drugs are those which can be acquired without a doctor's prescription.
}

regulation machinery, including the pharmaceutical sector.

In the case of Brazil, however, various investment incentives adopted by the federal and state governments remain in force. The latter enjoy fiscal powers which are even broader than those of the provinces in Argentina, so that they have considerable possibilities for granting fiscal incentives in the form of the reduction or financing of the goods and services turnover tax in order to attract new investments. State incentives are often also granted for labour training and development of infrastructure.

\footnotetext{
${ }^{4}$ The provisions on patents adopted in 1994 in the agreements on Trade-Related Intellectual Property aspects of the General Agreement on Tariffs and Trade (GATT) oblige countries, once they come into force, to provide patent protection for pharmaceutical products and the corresponding production processes. Although the developing countries were given a five-year period of grace, these agreements are having a profound impact on countries which did not recognize patents in this respect and had managed to develop industries based on imitative development efforts by local firms (such as India and Argentina).

5 The field studies consisted of standardized interviews with representatives of about 15 firms in each of the countries and the main trade associations of the sector.
} 
In Uruguay, the structural reforms have been more gradual (there has been practically no privatization of public enterprises), although the process of unilateral trade openness did advance during the 1990s (Laens, Lorenzo and Osimani, 1993; Torrello and Noya, 1992).

Since the early 1990 s, however, new policy instruments have been appearing which are designed to promote technological development and business restructuring, such as the Argentine Technological Fund (FONTAR), aimed at the promotion of technological innovation, and a variety of export incentives, such as temporary admission and export drawbacks, which have been used by most of the Argentine laboratories interviewed.

As part of the general tendencies to rationalize and reduce public intervention in industrial policy matters, substantial changes were made in all the MERCOSUR countries in the policies on regulation of the pharmaceutical sector, which was subject up to the late 1980s to severe restrictions in terms of price formation mechanisms and external suppliers. In the 1990s, in both Argentina and Brazil, a number of deregulatory measures were taken, beginning with the elimination of maximum price controls, although there are still substantial differences in regulations between the two countries in two fields: the registration of medicines and patent law.

With regard to the registration of medicines, Argentina has eased the rules in this respect in order to facilitate the importation of medicines as a means of fomenting competition with local products. To this end, in 1992 it set up the special register for authorized medicines. ${ }^{6}$ In Brazil, in contrast, the mechanism for the registration of medicines is much more restrictive, since it requires the submission of samples for analysis and a number of tests considered necessary by the health authorities. These requirements impose serious limitations on Brazilian imports of medicines from the MERCOSUR countries and oblige companies in those countries to establish agreements with Brazilian firms which have products that are already registered with the health authorities (De Queiroz, 1993).

\footnotetext{
${ }^{6}$ In that year, automatic registration was decreed for all medicinal specialities already circulating in the country, as well as for those which were authorized in the domestic markets of a number of countries considered to be of "high levels of sanitary supervision", a list of which is given in annex I of the decree in question. At the same time, a maximum deadline of 120 days was established for the authorization and registration of products similar to those already registered in the country, either for domestic production or for importation from countries listed in annex II.
}

With regard to the new patent legislation, this does not have retroactive effect in Argentina: i.e., it does not affect products which circulated in that country or were covered by patents granted in other countries prior to 1995 (when the new regulations came into effect). Moreover, new inventions of pharmaceutical products are not patentable in Argentina until five years after the publication of the law (Challú and Lewis, 1996). After that date, the patent-holders will enjoy a monopoly of their use for 20 years, provided that they are indeed effectively used, since when a patent is not used, the authorities are empowered to grant exploitation rights to third parties. "Exploitation" or "use" is considered to be the proper distribution and marketing of the product covered by the patent in question, whether through domestic production or importation. ${ }^{7}$

In Brazil, the patents law has been in force since it officially came into effect (May 1996) and it likewise provides that the use must be "effective", but unlike the Argentine law it considers that use or exploitation can only mean supply of the domestic market through the domestic manufacture of finished products. This means that if a firm wants to enjoy monopoly rights to use its invention, it must manufacture the product in Brazil. This requirement for domestic production has already given rise to an application for a panel by the United States, that is to say, an application for the case to be decided within the World Trade Organization (WTO) ${ }^{8}$

These differences between Argentina and Brazil with respect to patents law may turn out to be of decisive importance in the strategies adopted by pharmaceutical firms, encouraging them to operate plants in Brazil, since supplying a product from that country can give a patent-holder monopoly rights in both countries (as Argentina considers importation equivalent to use),

\footnotetext{
7 Towards the beginning of 2000, when the payment of pharmaceutical patents was to come into force in Argentina, there was a heated debate in that country as to whether the requirement of "exploitation" or "use" of patents should involve domestic production of the medicine in question, as in Brazil.

${ }^{8}$ Brazil, in turn, has just denounced the fact that the United States makes a similar stipulation for a number of medicines, and it recently won a vote in the Human Rights Commission (by 53 votes to 1) which condemned the abuse of patent rights by some pharmaceutical companies. Furthermore, under international pressure, a number of such companies have recently abandoned an action against South Africa for the use of basic drugs needed to treat AIDS. All this means that the discussion on patents law may take a new turn in the future (Watal and Mathai, 1995).
} 
whereas if a firm sets up a factory in Argentina it may be obliged to grant a licence to manufacture the product in Brazil. Moreover, the difference between the dates of entry into effect of the two laws (with regard to pharmaceutical products) may operate in the same direction during the transitional period in Argentina, in the case of the establishment of plants to use companies' own inventions. In this case, production in Brazil at least ensures monopoly rights in that country, whereas production in Argentina does not ensure this in either country.

Another aspect worthy of note is that in both countries there have been attempts to promote sales through generic medicines, but there is still a long way to go in this respect. In Argentina, it was decreed that lists of the trade names of medicines should be prepared, grouped together according to their generic names, and doctors were obliged to use the latter names when writing prescriptions, but this obligation proved hard to enforce, and in a later decree doctors were left free to write prescriptions as they saw fit. In Brazil, it was decreed in February 1999 that all medicines sold under brand names must clearly show on their packages the name of their active principles. ${ }^{9}$

Furthermore, within the process of harmonization of rules which is taking place in MERCOSUR, progress has been made in the rules on inspection of the quality of medicines, good manufacturing practices for them, inspection of manufacturing plants and guidelines therefor, and the training of inspectors. This harmonization process makes it possible to advance towards mutual recognition of the government agencies of both countries responsible for authorizing the sale of medicinal specialities in the respective domestic markets, and has also aided in the exchange and upgrading of know-how.

\section{III \\ Recent evolution of the pharmaceutical sector in MERCOSUR}

\section{Structure and recent performance}

The pharmaceutical sector of the different MERCOSUR countries displays some common structural features.

Firstly, there is a clear division between transnational and national laboratories. In Argentina and Uruguay, the turnover of the sector is divided more or less equally between the two types, but in Brazil the ratio is $75 \%$ to $25 \%$ in favour of the transnationals. ${ }^{10}$ The differences in ownership are also reflected in different types of microeconomic behaviour: the national laboratories generally do not carry out scientific and technological research and survive by copying medicines developed abroad, whereas the transnational laboratories apply in the local market the innovations made in world-level research centres. In both cases the active principles are mostly imported.

\footnotetext{
${ }^{9}$ In order to further this process, the Brazilian Health Supervision Agency was given 90 days to establish the criteria for determining the therapeutic equivalence of generic medicines and the exceptions to this rule when expressly requested by the prescribing physician. ${ }^{10}$ In the case of Uruguay, the category "national laboratories" also includes those of a binational or multi-Latin American nature.
}

Secondly, although the pharmaceutical market as a whole is not very concentrated (the ten main firms account for no more than $40 \%$ of total sales in Argentina and Brazil), within each therapeutic speciality the level of concentration is markedly greater. ${ }^{11}$ Promotion (largely through salesmen visiting doctors) and brand names are the main forms of competition, with competition on price only playing an important role in direct sale to public health systems (hospitals, etc.).

There are considerable differences between the various MERCOSUR countries as regards the size of firms. Thus, in Brazil over 50\% of the turnover is accounted for by big laboratories with over 500 employees, whereas in Uruguay most of the firms are small, and up to 1997 there was only one laboratory with more than 100 employees.

The demand structure also seems to differ significantly in the three countries studied. In Brazil, this structure is made up of almost a thousand

\footnotetext{
11 In the case of Brazil, for example, the share of the leading laboratory comes to $91 \%$ for the generic medicine paracetamol, $58 \%$ for amoxycillin, and $93 \%$ for dipirone.
} 
TABLE 1

Production and apparent consumption of pharmaceutical products in Argentina, Brazil and Uruguay

(Millions of current dollars)

\begin{tabular}{|c|c|c|c|c|c|c|c|c|c|}
\hline \multirow[b]{2}{*}{ Year } & \multicolumn{3}{|c|}{ Argentina } & \multicolumn{3}{|c|}{ Brazil } & \multicolumn{3}{|c|}{ Uruguay } \\
\hline & Production & $\begin{array}{c}\text { Trade } \\
\text { balance } \\
\text { (exports- } \\
\text { imports) }\end{array}$ & $\begin{array}{c}\text { Apparent } \\
\text { consumption }\end{array}$ & Production & $\begin{array}{c}\text { Trade } \\
\text { balance } \\
\text { (exports- } \\
\text { imports) }\end{array}$ & $\begin{array}{c}\text { Apparent } \\
\text { consumption }\end{array}$ & Production & $\begin{array}{c}\text { Trade } \\
\text { balance } \\
\text { (exports- } \\
\text { imports) }\end{array}$ & $\begin{array}{c}\text { Apparent } \\
\text { consumption }\end{array}$ \\
\hline 1988 & 1197 & -29 & 1226 & $\ldots$ & $\ldots$ & $\ldots$ & $\ldots$ & $\ldots$ & $\ldots$ \\
\hline 1989 & 927 & -24 & 951 & 7565 & -62 & 7606 & $\ldots$ & $\ldots$ & $\ldots$ \\
\hline 1990 & 1441 & -21 & 1462 & 10973 & -157 & 11276 & $\ldots$ & $\ldots$ & $\ldots$ \\
\hline 1991 & 2087 & -45 & 2132 & 8769 & -159 & 9090 & 146 & -14 & 160 \\
\hline 1992 & 2468 & -107 & 2575 & 9767 & -117 & 10009 & 147 & -26 & 173 \\
\hline 1993 & 3005 & -135 & 3140 & 12058 & -176 & 12476 & 185 & -41 & 236 \\
\hline 1994 & 3427 & -235 & 3662 & 14338 & -339 & 14993 & 183 & -50 & 233 \\
\hline 1995 & 3396 & -204 & 3600 & 17040 & -406 & 17964 & 193 & -57 & 250 \\
\hline 1996 & 3423 & -221 & 3644 & 17540 & -701 & 18575 & 201 & -75 & 276 \\
\hline 1997 & 3606 & -234 & 3840 & 19700 & -1170 & 20905 & $\ldots$ & $\ldots$ & $\ldots$ \\
\hline 1998 & $\ldots$ & $\ldots$ & $\ldots$ & 20313 & $\ldots$ & 21643 & $\ldots$ & $\ldots$ & $\ldots$ \\
\hline
\end{tabular}

Source: Argentina: on sales, Cámara Argentina de Especialidades Medicinales (CAEME); on external trade, Instituto Nacional de Estadísticas y Censos (INDEC). Brazil: on production and apparent consumption, Fundação Comércio Exterior (FUNCEX) (production data include perfumery and toiletry sector); on the trade balance, data prepared by the authors on the basis of data from the INTAL database. Uruguay: Uruguayan report with data from the Instituto Nacional de Estadística (INE).

distributors and 46,000 pharmacies. The distributors operate at the regional level, and only in recent years have they begun to operate at the national level. In Argentina, in contrast, the distribution of medicines is concentrated in three big firms in which the most important laboratories play an active part. These distributors have also moved into the level of the retail pharmacies, thus increasing still further the degree of concentration.

The apparent production and consumption of pharmaceutical products, measured in current dollars, displays an upward long-term trend, especially in Argentina and Brazil, as may be seen from table 1. In 1996 the output of the three countries studied amounted to US\$ 21 billion in current terms, of which Brazil accounted for $82 \%$, Argentina for $17 \%$ and Uruguay for the remaining $1 \% .^{12}$

However, the increases in production levels in current dollars reflect not only changes in physical output but also in the real exchange rate and the price levels of pharmaceutical products. If these increases

12 It should be noted that the production figures for Brazil also include the perfumery and toiletry sector, so that Brazil's share in the total MERCosur pharmaceutical market is somewhat overestimated. are measured at constant prices, the picture undergoes a radical change: only the Brazilian pharmaceutical industry registers an increase in the physical volume of production during the 1990s. This growth took place after the introduction of the Plano Real and amounted to $23.6 \%$ between 1994 and 1998 (which is still a long way from the $42 \%$ increase in output in constant dollars registered over the same period). In the case of Argentina, unit sales shrank by around $10 \%$ between 1991 and 1997, so that the whole of the increase in production in current dollars was due to the big increase in the average prices of the industry's production (Ministry of Economic Affairs of the Province of Buenos Aires, 1997).

This indicates that, in spite of the tariff reduction process which took place in the 1990s, the MERCOSUR pharmaceutical industry registered a sharp recovery in its relative prices during that decade.

\section{Evolution of trade in pharmaceutical products during the 1990 s}

\section{a) Total exports and imports}

MERCOSUR external trade in pharmaceutical products grew strongly in the 1990s, with imports growing more 
TABLE 2

MERCOSUR exports of pharmaceutical products

\begin{tabular}{|c|c|c|c|c|c|c|c|}
\hline & 1990 & 1991 & 1992 & 1993 & 1994 & 1995 & 1996 \\
\hline \multicolumn{8}{|c|}{ Thousands of dollars } \\
\hline Argentina & 21569 & 44556 & 48258 & 73656 & 91357 & 131303 & 179058 \\
\hline Brazil & 43884 & 50652 & 66129 & 62332 & 83174 & 111164 & 131178 \\
\hline Uruguay & 6091 & 14142 & 14119 & 12116 & 13460 & 23636 & 21597 \\
\hline Paraguay & 156 & 452 & 1328 & 2004 & 3689 & 2987 & 4293 \\
\hline MERCOSUR & 71700 & 109802 & 129834 & 150108 & 191680 & 269090 & 336126 \\
\hline \multicolumn{8}{|c|}{ Percentages } \\
\hline Argentina & 30 & 41 & 37 & 49 & 48 & 49 & 53 \\
\hline Brazil & 61 & 46 & 51 & 42 & 43 & 41 & 39 \\
\hline Uruguay & 8.5 & 13 & 11 & 8 & 7 & 9 & 6 \\
\hline Paraguay & 0.5 & 0 & 1 & 1 & 2 & 1 & 1 \\
\hline MERCOSUR & 100 & 100 & 100 & 100 & 100 & 100 & 100 \\
\hline
\end{tabular}

Source: Prepared by the authors on the basis of data from the INTAL database.

TABLE 3

MERCOSUR imports of pharmaceutical products

\begin{tabular}{|c|c|c|c|c|c|c|c|}
\hline & 1990 & 1991 & 1992 & 1993 & 1994 & 1995 & 1996 \\
\hline & \multicolumn{7}{|c|}{ Thousands of dollars } \\
\hline Argentina & 42322 & 89601 & 155955 & 207999 & 362362 & 335596 & 400896 \\
\hline Brazil & 200903 & 209423 & 183126 & 238692 & 422086 & 517319 & 832378 \\
\hline Uruguay & 21310 & 27397 & 36676 & 43460 & 54740 & 66659 & 79763 \\
\hline Paraguay & 11499 & 18962 & 23545 & 29038 & 50954 & 38913 & 45184 \\
\hline \multirow[t]{2}{*}{ MERCOSUR } & 276034 & 345383 & 399302 & 519189 & 854142 & 958487 & 1358221 \\
\hline & \multicolumn{7}{|c|}{ Percentages } \\
\hline Argentina & 15 & 26 & 39 & 40 & 38 & 35 & 30 \\
\hline Brazil & 73 & 61 & 46 & 46 & 49 & 54 & 61 \\
\hline Uruguay & 8 & 8 & 9 & 8 & 6 & 7 & 6 \\
\hline Paraguay & 4 & 5 & 6 & 6 & 6 & 4 & 3 \\
\hline MERCOSUR & 100 & 100 & 100 & 100 & 100 & 100 & 100 \\
\hline
\end{tabular}

Source: Prepared by the authors on the basis of data from the INTAL database.

than exports (tables 2 and 3). ${ }^{13}$ As a result, the trade deficit of the pharmaceutical sector widened from US\$ 204.3 million in 1990 to US\$ 1,022.1 million in 1996 (table 4).

Within this overall situation, the shares of the different MERCOSUR countries are not in line with their

${ }^{13}$ It should be noted that the primary data are taken from publications of the official statistical bodies of the countries. This gives rise to problems of reliability and consistency of the external trade figures. Thus, for example, exports FOB from Argentina to Brazil in 1989 (as declared by Argentina) came to US\$ 186,000, whereas imports CIF by Brazil from Argentina in the same year (as relative sizes both as regards exports and gross values of production, as Argentina and Uruguay account for relatively high proportions of total exports, whereas Brazil's share is relatively small for the country's size. In this sense, Argentina figures as the main exporter of the area, with $53 \%$ of its exports in 1996, while Brazil

declared by Brazil) came to US $\$ 1.8$ million, and Uruguay's exports FOB to Brazil in 1996 (as declared by Uruguay) came to US\$ 10.1 million, whereas the CIF value declared by Brazil came to US $\$ 20$ million. Generally speaking, there are big discrepancies between the FOB and CIF values declared by trading partners in intrazonal trade, and these differences are not always in the expected direction.

STATIC AND DYNAMIC IMPACTS OF MERCOSUR: THE CASE OF THE PHARMACEUTICAL SECTOR - MARTA BEKERMAN AND PABLO SIRLIN 
TABLE 4

MERCOSUR trade balance for pharmaceutical products

(Thousands of dollars)

\begin{tabular}{lrrrrrrrrrr}
\hline & 1990 & 1991 & 1992 & 1993 & & 1994 & 1995 \\
\hline Argentina & -20753 & -45045 & -107697 & -134343 & -235005 & -204293 & -221838 \\
Brazil & -157019 & -158771 & -116997 & -176360 & -338912 & -406155 & -701200 \\
Uruguay & -15219 & -13255 & -22557 & -31344 & -41280 & -43023 & -58166 \\
Paraguay & -11343 & -18510 & -22217 & -27034 & -47265 & -35926 & -40891 \\
MERCOSUR & -204334 & -235581 & -269468 & -369081 & -662462 & -689397 & -1022095 \\
\hline
\end{tabular}

Source: Prepared by the authors on the basis of data from the INTAL database.

TABLE 5

\section{Export coefficients}

(Percentages)

\begin{tabular}{lccc}
\hline & Brazil & Argentina & Uruguay \\
\hline 1991 & 1 & 2 & 10 \\
1992 & 1 & 2 & 10 \\
1993 & 1 & 2 & 7 \\
1994 & 1 & 3 & 7 \\
1995 & 1 & 4 & 12 \\
1996 & 1 & 5 & 11 \\
1997 & 3 & 7 & $\ldots$ \\
\hline
\end{tabular}

Source: Data on production: country reports for Argentina, Brazil and Uruguay. Data on trade: prepared by the authors on the basis of data from the INTAL database, except for Brazil in 1997, which was taken from the corresponding country report.

is the main importer, with $61 \%$ of the area's imports in that year.

As regards the degree of trade openness of the sector, it should be noted that the pharmaceutical industry of the MERCOSUR countries has been and continues to be aimed basically at the domestic market, as witness the low export coefficients (table 5). Nevertheless, in the 1990s exports grew faster than output, especially in Argentina.

The coefficients of openness to imports are slightly higher than the export coefficients, but even so (except in the case of Uruguay) the import penetration of pharmaceutical products continues to be relatively low. If the supply of raw materials for the industry (pharmaceutical chemicals) were taken into account, however, those coefficients would be substantially higher.

In the geographical pattern of external trade in pharmaceutical products in MERCOSUR, there is a marked difference between exports and imports. Exports to the zone account for a growing share of the total, as those destined for the rest of the world grow substantially slower and are mostly to developing countries, especially of Latin America (table 6).

Imports, in contrast (table 7), show that although the share of MERCOSUR member countries has grown in recent years, in 1996 imports from Brazil and Argentina only came to $10 \%$ or $12 \%$ of the total, indicating that the bulk of imports continue to come from the developed countries (the United States and Europe).

\section{b) Index of revealed comparative advantages}

In the 1990s the MERCOSUR countries were affected to a greater or lesser extent by marked macroeconomic fluctuations which had a heavy impact both on their global trade balances and on those corresponding to specific sectors of production. For this reason, in this article we will use the index of revealed comparative advantages ${ }^{14}$ (also called the index of contribution to the total balance), as a way of separating within the sectoral balances the effects of changes in the global trade balances.

Table 8 shows that in the pharmaceutical sector MERCOSUR has a revealed comparative disadvantage with the rest of the world which grew more pronounced during the 1990s. This means that the normalized trade deficit of the sector (discounting the effect of global trade deficits or surpluses) has increased in relation to the total volume of trade of the area. It may be deduced from this that there have been structural changes in the

\footnotetext{
${ }^{14}$ The index of revealed comparative advantages is constructed by deducting from the sectoral trade balance a theoretical value representing the sector's share in the global trade balance. This share is expressed in thousandths of total trade, and its value may vary between -500 and +500 (corresponding to complete specialization $)$. The formula for this indicator is: $\mathrm{VCR}=((\mathrm{Xi}-\mathrm{Mi})$ $-(\mathrm{Xi}+\mathrm{Mi}) /(\mathrm{X}+\mathrm{M}) *(\mathrm{X}-\mathrm{M})) * 1000 /(\mathrm{X}+\mathrm{M})$.
} 
TABLE 6

Destination of exports by Argentina, Brazil and Uruguay

(Percentages)

\begin{tabular}{llccccccc}
\hline & Destination/year & 1990 & 1991 & 1992 & 1993 & 1994 & 1995 & 1996 \\
\hline \multirow{2}{*}{ Argentina } & MERCOSUR & 44 & 41 & 48 & 49 & 56 & 53 & 61 \\
& Rest of world & 56 & 59 & 52 & 51 & 44 & 47 & 39 \\
\multirow{3}{*}{ Brazil } & MERCOSUR & 8 & 14 & 20 & 22 & 27 & 37 & 41 \\
& Rest of world & 92 & 86 & 80 & 78 & 73 & 63 & 59 \\
\multirow{2}{*}{ Uruguay } & MERCOSUR & 28 & 70 & 55 & 58 & 56 & 70 & 58 \\
& Rest of world & 72 & 30 & 45 & 42 & 44 & 30 & 42 \\
\hline
\end{tabular}

Source: Prepared by the authors on the basis of data from the INTAL database.

TABLE 7

Origin of imports by Argentina, Brazil and Uruguay

(Percentages)

\begin{tabular}{llrrrrrrr}
\hline & Destination/year & 1990 & 1991 & 1992 & 1993 & 1994 & 1995 & 1996 \\
\hline \multirow{2}{*}{ Argentina } & MERCOSUR & 1 & 4 & 6 & 6 & 5 & 12 & 12 \\
& Rest of world & 99 & 96 & 94 & 94 & 95 & 88 & 88 \\
\multirow{2}{*}{ Brazil } & MERCOSUR & 1 & 5 & 6 & 5 & 6 & 8 & 10 \\
& Rest of world & 99 & 95 & 94 & 95 & 94 & 92 & 90 \\
\multirow{5}{*}{ Uruguay } & MERCOSUR & 28 & 40 & 36 & 38 & 42 & 41 & 42 \\
& Rest of world & 72 & 60 & 64 & 62 & 58 & 59 & 58 \\
\hline
\end{tabular}

Source: Prepared by the authors on the basis of data from the INTAL database.

TABLE 8

Index of revealed comparative advantages in the MERcosuR pharmaceutical sector

(Thousandths of total trade)

\begin{tabular}{lccccccc}
\hline & 1990 & 1991 & 1992 & 1993 & 1994 & 1995 & 1996 \\
\hline Argentina & -3.22 & -3.44 & -3.20 & -3.36 & -4.56 & -5.23 & -4.68 \\
Brazil & -3.99 & -4.01 & -3.28 & -3.46 & -4.93 & -4.02 & -6.42 \\
Uruguay & -5.71 & -4.35 & -5.35 & -5.47 & -6.88 & -5.91 & -7.31 \\
Paraguay & -4.68 & -6.62 & -7.65 & -7.47 & -7.72 & -3.60 & -4.61 \\
MERCOSUR & -3.99 & -4.05 & -3.83 & -4.03 & -5.36 & -4.45 & -5.90 \\
\hline
\end{tabular}

Source: Prepared by the authors on the basis of data from the INTAL database.

pattern of trade which are not exclusively due to the change in macroeconomic conditions that took place in the 1990s.

This overall behaviour of the pharmaceutical sector corresponds more or less closely to the individual cases of the MERCOSUR countries. In all of them, exports and imports expanded at a rapid rate and the sectoral trade deficit and revealed comparative disadvantage have tended to grow worse.

\section{Intrazonal trade in MERcosuR}

As a result of the regional integration process, intrazonal trade has grown even faster than trade outside the area. Thus, during the period studied, intrazonal exports grew by $1,110 \%$, from US\$ 14.6 million in 1990 to US\$ 176.7 million in 1996 (tables 9 and 10).

In intrazonal exports, it may be seen that Argentina's leading position in exports is even more

STATIC AND DYNAMIC IMPACTS OF MERCOSUR: THE CASE OF THE PHARMACEUTICAL SECTOR • MARTA BEKERMAN AND PABLO SIRLIN 
TABLE 9

Intra-MERCOSUR exports of pharmaceutical products

\begin{tabular}{|c|c|c|c|c|c|c|c|}
\hline & 1990 & 1991 & 1992 & 1993 & 1994 & 1995 & 1996 \\
\hline \multicolumn{8}{|c|}{ Thousands of dollars } \\
\hline Argentina & 9553 & 18138 & 23025 & 36170 & 50836 & 69056 & 108584 \\
\hline Brazil & 3385 & 7038 & 13343 & 13390 & 22197 & 41280 & 53735 \\
\hline Uruguay & 1692 & 9927 & 7814 & 7040 & 7502 & 16642 & 12614 \\
\hline Paraguay & 16 & 281 & 684 & 1187 & 2515 & 828 & 1772 \\
\hline MERCOSUR & 14646 & 35384 & 44866 & 57787 & 83050 & 127806 & 176705 \\
\hline \multicolumn{8}{|c|}{ Percentages } \\
\hline Argentina & 65 & 51 & 51 & 63 & 61 & 54 & 61 \\
\hline Brazil & 23 & 20 & 30 & 23 & 27 & 32 & 30 \\
\hline Uruguay & 12 & 28 & 17 & 12 & 9 & 13 & 7 \\
\hline Paraguay & 0 & 1 & 2 & 2 & 3 & 1 & 1 \\
\hline MERCOSUR & 100 & 100 & 100 & 100 & 100 & 100 & 100 \\
\hline
\end{tabular}

Source: Prepared by the authors on the basis of data from the INTAL database.

TABLE 10

Intra-MERCOSUR imports of pharmaceutical products

\begin{tabular}{|c|c|c|c|c|c|c|c|}
\hline & 1990 & 1991 & 1992 & 1993 & 1994 & 1995 & 1996 \\
\hline \multicolumn{8}{|c|}{ Thousands of dollars } \\
\hline Argentina & 626 & 3315 & 9809 & 12484 & 17426 & 39648 & 48915 \\
\hline Brazil & 2310 & 9582 & 10244 & 12313 & 24227 & 42765 & 79435 \\
\hline Uruguay & 6056 & 10882 & 13207 & 16586 & 22793 & 27176 & 33659 \\
\hline Paraguay & 6460 & 10099 & 12370 & 16870 & 19434 & 22554 & 29169 \\
\hline MERCOSUR & 15452 & 33878 & 45630 & 58253 & 83880 & 132143 & 191178 \\
\hline \multicolumn{8}{|c|}{ Percentages } \\
\hline Argentina & 4 & 10 & 21 & 21 & 21 & 30 & 26 \\
\hline Brazil & 15 & 28 & 22 & 21 & 29 & 32 & 42 \\
\hline Uruguay & 39 & 32 & 29 & 28 & 27 & 21 & 18 \\
\hline Paraguay & 42 & 30 & 27 & 29 & 23 & 17 & 15 \\
\hline MERCOSUR & 100 & 100 & 100 & 100 & 100 & 100 & 100 \\
\hline
\end{tabular}

Source: Prepared by the authors on the basis of data from the INTAL database.

pronounced than in exports to the world as a whole (indicating greater dependence by Argentina on the area market). On the import side, it may be seen that Uruguay and Paraguay have much greater relative weight (i.e., both of them purchase a relatively greater proportion of their imports from other MERCOSUR countries).

This behaviour of the trade flows gives rise to an intrazonal trade pattern in which Argentina increasingly figures as the only country with a trade surplus, whereas Uruguay, Paraguay and, since 1994, Brazil have deficits (table 11).

The faster growth of intrazonal exports compared with those to the rest of the world reflects a general trend in the trade of MERCOSUR's trading partners. The zonal orientation index ${ }^{15}$ (table 12) shows that, in the cases of Argentina and Brazil, pharmaceutical exports register a zonal orientation which is substantially greater than 1 . In other words,

15 The zonal orientation index compares the relative importance of the zonal market for the sector's exports with its importance for the country's total exports. The indicator ranges from zero to infinity. A value of 1 suggests that there is no zonal orientation. The corresponding formula is:

$$
\mathrm{IORi}=\mathrm{Xij} / \mathrm{Xi} / \mathrm{Xj} / \mathrm{X} \text {. }
$$


TABLE 11

Intra-MERCOSUR trade balance for pharmaceutical products

(Thousands of dollars)

\begin{tabular}{lrrrrrrrrr}
\hline & 1990 & 1991 & 1992 & 1993 & 1994 & 1995 \\
\hline Argentina & 8927 & 14823 & 13216 & 23686 & 33410 & 29408 \\
Brazil & 1075 & -2544 & 3099 & 1077 & -2030 & -1485 & -25700 \\
Uruguay & -4364 & 955 & -5393 & -9546 & -15291 & -10534 & -21045 \\
Paraguay & -6444 & -9818 & -11686 & -15683 & -16919 & -21726 & -27397 \\
\hline
\end{tabular}

Source: Prepared by the authors on the basis of data from the INTAL database.

TABLE 12

Zonal orientation index in the pharmaceutical sector

\begin{tabular}{lllllll}
\hline & 1990 & 1991 & 1992 & 1993 & 1994 & 1995 \\
\hline Argentina & 4.56 & 3.47 & 3.88 & 2.47 & 2.88 & 2.33 \\
Brazil & 1.90 & 2.05 & 1.96 & 1.78 & 2.31 & 3.09 \\
Uruguay & 0.72 & 4.29 & 2.49 & 2.00 & 1.43 & 3.84 \\
Paraguay & 0.17 & 3.03 & 1.77 & 2.21 & 3.00 & 0.29 \\
\hline
\end{tabular}

Source: Prepared by the authors on the basis of data from the INTAL database.

the pharmaceutical exports of Argentina ${ }^{16}$ and Brazil depend on intrazonal markets relatively more than the total exports of each of those countries. In Brazil, however, that zonal orientation displays an upward trend during the decade, whereas in Argentina the trend is downward.

\section{IV}

\section{Static and dynamic effects of trade openness, integration and changes in regulations on the pharmaceutical sector}

The pharmaceutical industry is going through a process of profound change, both at the zonal and the international level. The enterprises in this sector have had to adapt to new ways of carrying out their scientific and technological research processes, new systems of regulation (based fundamentally on trade liberalization

\footnotetext{
16 The fact that there is a positive zonal orientation in the case of Argentina is due to the fact that most of that country's primarysector exports go to the "rest of the world". If, instead of taking total exports as our reference point, we used exports of manufactures, the opposite result would be obtained, because pharmaceutical exports depend more on the zonal market than primary exports, but less than the average for manufactures.
}

and the elimination of price controls), new market signals, and new patterns of relations with public and private bodies. In other words, the regional integration process (through MERCOSUR) has coincided with other structural changes that have taken place in the area. This faces us with the methodological difficulty of identifying which of the aspects of the process of change in the sector which we discussed earlier can be attributed to the effects of regional integration and which are due rather to the impact of the other phenomena mentioned. In the following sections we will try to answer this question with regard to both static and dynamic effects. 


\section{Analysis of the static effects}

Static analyses of integration and openness processes are generally aimed at determining to what extent those processes reduce the static distortions induced by trade protection. Such analyses tend to center on the behaviour of imports and the extent to which they displace inefficient domestic production, but they also involve the evaluation of domestic price trends and their effect on the well-being of consumers.

From that view of the behaviour of trade, there can be no doubt that both trade openness and regional integration have generated static benefits in the area. The total imports of the three countries studied have increased, proportionately, much more than their respective levels of apparent consumption. This has markedly increased the sectoral imbalance of the area with the rest of the world and raised its import coefficients (although these continue to be relatively low). There has consequently been a gradual decline in the index of revealed comparative advantages of the zone compared with the rest of the world, affecting each of the four countries of the area more or less equally.

At the same time, the integration process has made possible a notable increase in intrazonal trade. Both imports and exports are over ten times greater than they were at the end of the 1980s. The fact that imports from outside the area have also increased, while levels of production have grown much less, gives grounds for assuming that there has been a considerable process of creation of trade in the area.

The trade pattern of the area shows us that the bulk of its imports continue to come from the developed countries, while the increase in the latter's exports to MERCOSUR have turned it into their main export destination.

The increase in the area's exports has been led by Argentina, which has consolidated its position as export leader of MERCOSUR and continues to be the only country with a positive sectoral balance. In spite of the strong progress made by Brazil as a market for Argentina's exports, however, this mainly benefits the transnational corporations operating in the sector, since the exports of the local-capital firms go rather to the Uruguayan and Paraguayan markets. ${ }^{17}$ This is attributed by Argentine firms to the regulatory asymmetries between Argentina and Brazil and the fact that in order to export to Brazil it is necessary to make heavy

17 And also to other Latin American countries, especially those where the local-capital laboratories have plants of their own. investments to win a place for their brands in that market.

In Brazil, too, the transnational corporations occupy a leading place in exports. There, out of the ten main enterprises exporting to MERCOSUR (which account for some $70 \%$ of total exports), eight are transnationals and two are in the "unclassified" category, while none of the main national laboratories figure among the largest exporters to the area. The transnational corporations also figure among the main MERCOSUR importers of products. A number of transnational corporations act both as importers and exporters of pharmaceutical products, reflecting an intra-industry specialization strategy.

The intrazonal trade structure would appear to reflect a specialization pattern marked by the export of bulk medicines and the importation of retail medicines by Uruguay, while there is intra-industry specialization between Argentina and Brazil in retail medicines (with a high proportion of antibiotics, hormones and enzymes, anti-inflammatories, etc.).

To sum up, the increase in tariff preferences in MERCOSUR has clearly given rise to faster growth of intrazonal exports than of exports to the rest of the world: a process in which the transnational corporations have been the clear leaders. This has also been accompanied by an upward trend in imports from the rest of the world, however, though this gives no grounds for inferring the existence of diversion of trade and has led to a slight decline in the index of intra-industry trade and an erratic tendency in the zonal orientation index during the decade.

The local-capital enterprises of all the countries studied complain that there are asymmetries in the regulations which make it difficult to take advantage of the existing comparative advantages or that there is a danger of excessive penetration by imports. The Argentine enterprises claim that the restrictions on access to the registration of medicines in Brazil mean that only the transnational corporations can benefit from the expansion of exports to that country. The problem is that local-capital Argentine firms must undergo stringent quality controls of their plants and products, which limits the entry of their products into the neighbouring country. Brazilian firms, for their part, claim that health control rules are looser in Argentina because there are fewer requirements as regards the licensing and quality control of medicines, and this affects the competitiveness of Brazilian products. Another static effect of the greater trade openness in Argentina and Brazil has been a sharp increase in

STATIC AND DYNAMIC IMPACTS OF MERCOSUR: THE CASE OF THE PHARMACEUTICAL SECTOR • MARTA BEKERMAN AND PABLO SIRLIN 
imports of pharmaceutical products, which has helped to bring down the production costs of the pharmaceutical industry considerably.

It is interesting to note that the apparent positive static effects of the behaviour of trade flows are in sharp contrast with the behaviour of domestic prices, since the domestic prices of medicines in the three countries studied kept on rising throughout the 1990s.

In the case of Argentina, in particular, unit sales stagnated (and even went down slightly, depending on the years compared), whereas average prices in dollars registered a constant increase which amounted to $100 \%$ between 1991 and 1997 and $240 \%$ if 1988 is taken as the starting point (data from CAEME). This means that consumers have been seriously prejudiced by the effects of the various changes that have taken place in the sector. This trend towards higher prices is compounded by some special characteristics of the health market, such as the differentiation between those who decide the expenditure that must be made - the doctors - and those who have to pay it, or the existence of more or less generalized health insurance arrangements. These characteristics tend to give rise to excessive use of medicines and an inability to negotiate over their prices by those who have to foot the bill (fundamentally the consumers).

\section{Dynamic effects of the integration process}

As we saw in section III, the pharmaceutical sector of the area is going through a far-reaching process of change. This is giving rise to big changes in the ways of developing, manufacturing and marketing medicines, through modifications in the forms of conduct and strategies of the companies and institutions of the sector. As we shall see below, the strategies differ considerably, depending on whether they involve local-capital firms or subsidiaries of transnational corporations.

How far has the integration process influenced these changes? Both in Argentina and in Brazil, companies have attached less importance to integration as a catalyst of change than to changes in the regulations (maximum prices, trade openness, the law on patents) and macroeconomic stabilization. We will now describe some of the areas where the integration process might have been expected to have dynamic positive effects.

\section{a) The pressures of competition and conversion of the sector}

As we already noted, neither the integration process nor greater openness have so far given rise to greater pressure through competition on the domestic prices of the MERCOSUR countries. This may be attributed to the market structure of the sector, in which medicinal specialities generally have captive markets due to the brand name (thanks to powerful promotional campaigns) and in some cases strong concentration of distribution is also taking place. Moreover, in many cases the importation of medicines is controlled by the producer laboratories themselves, so that the capacity of imports to discipline prices is severely limited.

Although no competitive pressure on domestic prices has been observed in the area, however, there are clear signs of a new situation in terms of competition due to the important changes that have been made in the regulations, especially as regards patent law. The changes caused by this new situation are so profound that there is reason to doubt the viability of the localcapital laboratories, especially the smaller ones.

The entry into force of the regulations on patents narrows the production horizons of local firms, since it limits their possibilities of participating in the production of the new products which are coming onto the market and which are usually the most profitable ones.

In view of this situation, the options open to local firms are to seek agreements with the transnational corporations, concentrate increasingly on the market for generic drugs, or simply sell their plants.

The strategies of the larger firms seem to be increasingly aimed at securing new kinds of strategic alliances with the transnational corporations which would allow them to gain early access to production licences through joint marketing agreements or to act as local distributors of the molecules and active principles developed by those corporations abroad.

In order to improve their bargaining capacity with foreign companies, one of the strategies which is being increasingly used by the local laboratories of various countries is to strengthen their marketing structures and build up the prestige of their brands and the level of confidence in them.

Greater participation in the market for generic products is not an obvious solution for Argentine companies. When an attempt was made there to impose legislation to promote the use of those products, it was seriously questioned by various sectors of the industry. Since generic products require a modern industry and high scales of production in order to keep costs down, they have been developed to a greater extent in Brazil, because of the large size of the local market.

This situation suggests that the tendency towards increased participation by foreign companies in the 
markets of Brazil and Argentina will be further strengthened in the future. The integration process has increased the interest of the transnational corporations in strengthening their position in those markets. MERCOSUR offers them greater possibilities for expanding intra-firm trade, because of the regional tariff liberalization, the geographical proximity of the markets, and the prospects that in the future a high level of harmonization of regulations will be achieved among the member countries. The most common strategy adopted by those firms in Argentina, and especially in Brazil, is to revitalize their production facilities, acquire existing plants, and establish new distribution and marketing networks.

In Uruguay, however, the opposite is taking place, for the transnational corporations established in that country are tending to give up local production and sell only imported medicines, particularly from Argentina. Some of the plants closed down by those companies have been or are being bought by local firms or "multilatins": i.e., Latin American companies which have operations in that country and in some other MERCOSUR nation (Laens and Terra, 1998).

The repositioning of the transnational corporations in Argentina and Brazil is taking place by various means: some of them acquired companies which previously belonged to local interests (Bristol-Myers bought Argentia in Argentina) or merged with them (Hanssen with Cilag Farma in Argentina; Merck, Sharp and Dohme with Ache in Brazil), while some firms which had lost dynamism during the 1980s recovered their positions by rehabilitating and improving their existing factories (Rhodia Farma in Brazil). Finally, some firms opened new laboratories or embarked on expansion projects involving the construction of pharmaceutical plants (Bayer in Argentina; Glaxo Wellcome and Pfizer in Brazil). This restructuring process has also included the transfer of production plants from one country to another, such as the closure of plants in Uruguay and also in Argentina (Alcon) for their relocation to Brazil.

Thus, except in Uruguay, over the last few years market shares by capital origin have been changing in the area in favour of the transnational laboratories. The latter, however, show little or no interest in expanding their capacity for the production of active principles or pharmaceutical raw materials. Indeed, after the trade openness process a number of transnational corporations gave up producing active principles and opted for a policy of managed intra-firm imports. National firms too have been replacing the local production of active principles with imports. ${ }^{18}$ This process, which has enabled the laboratories to obtain a reduction in the cost of their raw materials, has considerably increased the trade deficit of the pharmaceutical industry of the area.

\section{b) Production specialization and reduction of the range of products}

The MERCOSUR integration process is accentuating a trend arising from the globalization strategies of the transnational corporations, which allow them to make use of the advantages developed by the countries in locating their different lines of medicines among them. This enables them to reduce their range of products and increase the production specialization of their various subsidiaries, thus favouring a big increase in intra-firm trading relations. As a result of this process, for example, Glaxo has made its Argentine plants specialize in antibiotics and its Brazilian ones in tablets and creams, while Roche produces vitamins in its Argentine plants and imports injectable products from Brazil.

In the case of local-capital firms, the Argentine laboratories interviewed are using two mechanisms in order to reduce their product range. On the one hand, they are reducing the amount of products they place on the market, thus enabling them to concentrate their research and marketing efforts. On the other hand, a number of firms have established supply agreements with other national firms for the mutual supply of different types of products which they then sell under their own brands, because of the need to increase their competitiveness (through economies of scale), as well as for health reasons (one laboratory cannot produce different lines of medicines.

The local-capital laboratories of Uruguay are also reducing their product ranges, giving up the production of certain lines, which they have begun to import from Argentina, and specializing in others in order to take advantage of economies of scale and brands which are common to both countries. In the case of Brazil, it is the transnational laboratories which can benefit by relocating their production activities among the MERCOSUR countries.

\footnotetext{
18 This is not the case in Uruguay, which has not developed the production of active principles, so that the pharmaceutical firms of that country, which no longer see the area as a source of supply of raw materials, are calling for a reduction on the common external tariff levied on them.
} 


\section{c) Export strategies and regional business alliances}

As already noted, MERCOSUR has favoured trade relations among transnational corporations in the area, giving rise to the expansion of intra-firm trade. Only in a few cases has there been an increase in trade between Argentina and Brazil due to the exports of local firms. The Argentine firms claim that this is very difficult because of the restrictions on the certification of products in the Brazilian register and the need to make heavy investments in marketing. In this respect, the impact of area integration on strategic export-based development has been felt above all in the case of exports to the smaller countries of the area. This is particularly noteworthy in the case of locally-owned enterprises which have plants in Argentina and Brazil, such as Elea, Bagó and Raffo. Some of the local firms interviewed say that such exports to MERCOSUR have enabled them to carry out a learning process with regard to export activities.

According to the transnational corporations located in Brazil which were interviewed, MERCOSUR has not significantly altered their behaviour in the markets of the area because their business strategies are based to a much larger extent on their relations with their head offices. Brazilian local-capital firms, however, display defensive strategies with respect to MERCOSUR, which they attribute to the fact that they consider it a market with little growth potential, but which may in fact be connected with their lower competitiveness compared with the Argentine plants.

The restrictions referred to by the local-capital firms of the MERCOSUR countries mean that in order to expand their trade in the area they need a local partner in one of the other countries of the bloc. So far, practically no trade or production agreements have been made between localcapital firms of Argentina and Brazil. From the point of view of the Argentine firms, the possibilities of association are limited because of the relative weakness of the Brazilian firms, while the latter, as already noted, take a defensive stance which they attribute to the unfavourable asymmetry of the regulations.

In both countries, however, there have been trade agreements led by companies which have made technological advances of their own. ${ }^{19}$

\footnotetext{
19 In Brazil, the Macrobiológica company (which has made advances in the production of active principles) signed a trade agreement with an Argentine firm to sell raw materials to the latter, while in Argentina the Bio Sidus company (which has made advances of its own in the field of biotechnology) has also made a
}

d) Development of technological capacity, capture of certain market niches, and strengthening of marketing structures

The fundamental research of the transnational corporations is concentrated outside the region. While innovation is part of the world strategy for those companies, at the local level it seems to be directed more towards organizational changes, especially in business management and marketing.

Some local-capital Argentine laboratories are carrying out applied research, and for this purpose they have signed collaboration agreements with universities and research centres, aided by the loans made by the Fondo Tecnológico Argentino. In a few cases, these agreements have enabled them, as already noted earlier, to make technological advances of their own, especially in the field of biotechnological products. The levels of investment in scientific and technological research are low, however, and it is not possible to advance beyond a certain point because of the high cost of securing registration in the countries of the north.

Other local-capital Argentine firms are carrying out product differentiation processes with regard to both the characteristics of medicines and their packaging. In other cases, they have tended to engage in production for certain market niches, such as natural plant-based medicinal products, which are not patentable. The impression which emerges from the interviews, however, is that, because of their lower level of scientific and technological maturity, except in a few cases the local-capital firms have opted to give up their previous in-house scientific and technological research efforts.

The strategies of the Argentine and Brazilian localcapital firms appear to be highly conditioned by the economic openness process and the patents law, which imposes limitations regarding the launching of new products which will come into effect immediately (for Brazilian firms) or in the near future (for Argentine companies). This augurs future setbacks in their respective domestic market shares.

\section{e) Some pending issues in the integration process}

It may be concluded from this study that the MERCOSUR integration process in the pharmaceutical products sector is still at a very incipient stage, in that the

trade agreement with a Brazilian firm, in open competition with transnational corporations, which has made it the fifth largest exporter of pharmaceutical products to Brazil and enabled it to increase its shares of both the Brazilian and the Latin American markets. 
liberalization of trade in this field among the countries of the area is still far from being sufficient to form an integrated market. Among the tasks which are still outstanding in order to achieve this objective and strengthen the development of dynamic comparative advantages over third countries, mention may be made of the following:

i) Elimination of asymmetries in regulations. This involves a broad range of policies and actions of the national public health bodies, such as harmonization of the rules on product licensing and the certification of bio-equivalent products, the health standards needed for the importation of medicines, regulations on the marketing of generic products, etc. It also includes the harmonization of policies which are the responsibility of other public bodies, such as those on patent law and policies on competition in the marketing of products.

ii) Promotion of technological cooperation agreements in order to further the area's development in this field. An example of action taken in this field is the Argentine-Brazilian Biotechnology Agreement (CABIO), adopted in 1986. Indeed, a number of studies suggest that priority should be given to the technological efforts of the countries of the periphery in the areas of biotechnology and fine chemicals, since they cover a wide field and could be applied in a relatively short space of time. CABIO registered only limited success, but this does not mean that strategies to promote technological agreements at the zonal level should be abandoned. The present study bears witness to the different performance in terms of trade and business dynamism displayed by firms which have made technological innovations of their own.

iii) Reduction of the obstacles to competition represented by captive brand-name markets, through a faster transition towards the consumption of generic products (Katz, 1997). This process is making most progress in Brazil. At the national level, it will make it possible to advance in the deregulation of the pharmaceutical products market, while minimizing the negative impact of this process on the well-being of consumers. At the zonal level, it will increase the capacity of localcapital laboratories to compete in their countries' markets. One of the most serious problems in this connection is the lack of information of doctors and consumers regarding the quality of generic products. Coordination among the countries of the area could help to increase their capabilities both as regards past experience and legislation to facilitate this transition and as regards all aspects of the certification of bio-equivalent products.

(Original: Spanish)

\section{Bibliography}

Challú, P. and P. Lewis (1996): Adecuación de la ley argentina de patentes al GATT, Baltimore, Maryland, Abeledo Perrot.

Katz, J. (1997): Apertura económica y desregulación en el mercado de medicamentos, Baltimore, Maryland, Alianza Editorial.

Laens, S., F. Lorenzo and R. Osimani (1993): Macroeconomic Conditions and Trade Liberalization: The Case of Uruguay, Montevideo, CINVE.

Laens, S. and M. I. Terra (1998): Formación de la Unión Aduanera, sectores afectados y análisis de los flujos de comercio, Montevideo, unpublished.

Ministry of Economic Affairs of the Province of Buenos Aires (1997): La industria farmacéutica argentina ante el nuevo contexto macroeconómico, 1991-1996, "Cuadernos de economía de la Provincia de Buenos Aires" series, No. 28, Buenos Aires.
De Queiroz, S. (1993): Competitividade da indústria de fármacos, Estudo da competitividade da indústria brasileira, Campinas, Brazil, State University at Campinas (UNICAMP)/Federal University of Rio de Janeiro, Institute of Industrial Economy/ Food and Drug Administration (FDA)/Centre for Foreign Trade Studies Foundation.

Torrello, M and N. Noya (1992): Las políticas de incentivos a la inversión privada, Informe de investigación, No. 23, Montevideo, CINVE.

Watal, J. and A. P. Mathai (1995): Sectoral Impact of the Uruguay Round Agreements on Developing Countries: Pharmaceutical Industry, New Delhi, United Nations Industrial Development Organization (UNIDO). 